\title{
Kajian Communibiology dalam Komunikasi Keluarga untuk Mendukung Perwatan Penderita Gagal Ginjal Kronis
}

\author{
Dewanto Putra Fajar ${ }^{1}$, Azizun Kurnia Illahi ${ }^{2}$ \\ ${ }^{1,2}$ Ilmu Komunikasi, Universitas Brawijaya \\ Email: dewanto.pf@ub.ac.id
}

\begin{abstract}
Chronic kidney failure is a degenerative disease that causes the sufferer to experience not only physiological and psychological disorders but also social problems. Interestingly, the social problems experienced by sufferers of chronic kidney failure are likely to increase the physiological and psychological disorders of the sufferer. Therefore, communication to build support for people with chronic kidney failure has a big role to play in increasing self-confidence in people with chronic kidney failure, which indirectly reduces the appearance of physiological and psychological disorders in sufferers of chronic kidney failure. This study seeks to comprehensively describe the aspects of communibiology in the communication process to provide moral support to sufferers of chronic kidney failure. This research is qualitative research using a case study methodological approach and literatur review. The literatur review is used to provide a detailed explanation of the communibiological processes in individuals and is used to strengthen the researchers' analysis of the observed phenomena. This study provides a big picture that communibiology processes play an important role in the communication processes carried out by families with chronic kidney failure to provide moral support to sufferers, as well as by people with chronic kidney failure to families who provide support, and when sufferers build trust. themselves when facing their social environment. Researchers concluded that moral and spiritual support through family communication has a positive role for chronic kidney failure sufferers to continue treatment and build self-confidence in their social environment.
\end{abstract}

Keywords: family communication; interpersonal communication; communibiology; chronic kidney failure

\begin{abstract}
Abstrak: Penyakit gagal ginjal kronis merupakan penyakit degeneratif yang menjadikan penederitanya tidak hanya mengalami gangguan secara fisiologis dan psikologis, tapi juga permasalahan sosial. Menariknya permasalahan sosial yang dirasakan oleh penderita gagal ginjal kronis sama kemungkinan besar justru meningkatkan gangguan fisiologis dan psikologis penderita. Karena itu, komunikasi untuk membangun dukungan kepada penderita gagal ginjal kronis memiliki peran besar untuk meningkatkan kepercayaan diri kepada penderita gagal ginjal kronis, yang secara tidak langsung mengurangi munculnya gangguan fisiologis dan psikologis kepada penderita gagal ginjal kronis. Penelitian ini berusaha menggambarkan secara komprehensif aspek communibiology dalam proses komunikasi untuk memberikan dukungan moral kepada penderita gagal ginjal kronis. Penelitian ini merupakan penelitian kualitatif menggunakan pendekatan metodologis studi kasus dan kajian literatur. Kajian literatur digunakan untuk memberikan penjelasan detail tentang proses-proses communibiology dalam diri individu, serta digunakan untuk menguatkan analisis peneliti terhadap fenomena yang diamati. Penelitian ini menghasilkan gambaran besar bahwa proses-proses communibiology berperan penting kepada proses-proses komunikasi yang dilakukan oleh keluarga penderita gagal ginjal kronis untuk memberikan dukungan moral kepada penderita, serta dilakukan oleh penderita gagal ginjal kronis kepada keluarga yang memberikan dukungan, serta ketika penderita membangun kepercayaan diri ketika menghadapi lingkungan sosialnya. Peneliti menyimpulkan bahwa dukungan moral dan spiritual melalui komunikasi keluarga berperan positif kepada penderita gagal ginjal kronis untuk melanjutkan perawatan serta membangun kepercayaan diri terhadap lingkungan sosialnya.
\end{abstract}

Kata kunci: komunikasi keluarga; komunikasi interpersonal; communibiology; gagal ginjal kronis

\section{Pendahuluan}

Proses komunikasi tidak hanya dimaknai sebagai proses penyampaian pesan dari komunikator ke komunikan, tetapi juga sebuah proses yang bermakna lebih dalam, karena bisa 
digunakan untuk beragam niat dan tujuan, termasuk di antaranya ialah membangun dukungan. Komunikasi juga berperan penting bagi penderita gagal ginjal kronis, khususnya komunikasi yang dilakukan oleh keluarga dekat-sebagai pandamping penderita gagal ginjal kronis. Dukungan kepada penderita gagal ginjal kronis menjadi penting, karena penderita gagal ginjal kronis mengalami ketegangan, kecemasan, dan gangguan psikologis, akibat perubahan kondisi fisik dan fisiologis penderita. Kecemasan dan gangguan psikologis pada diri penderita kemungkinan besar mempengaruhi perilaku komunikasi penderita gagal ginjal kronis dengan lingkungan sekitarnya. Sederhananya, penderita gagal ginjal cenderung berkomunikasi secara negatif, yang mungkin saja mengarah pada banyak hal yang bersifat negatif. Karena itu penderita perlu mendapatkan dukungan dari lingkungan sekitarnya melalui proses-proses komunikasi yang bersifat positif. Secara umum, komunikasi memiliki sejumlah tujuan, termasuk di antaranya menyebarkan sejumlah besar informasi kepada orang lain, untuk menjelaskan segala sesuatu yang bersifat abstrak (Cobley, 2008), sehingga lebih mudah dipahami oleh individu lainnya. Dengan demikian, proses komunikasi secar umum bisa digunakan untuk membangun semangat dan psikologi positif penderita gagal ginjal kronis.

Apabila digunakan secara baik dan dengan tujuan positif, proses komunikasi bisa memberikan semangat bagi penderita gagal ginjal kronis untuk terus melakukan perawatan, sehingga penderita memiliki kualitas hidup lebih baik. Komunikasi dalam keluarga menjadi penting bagi penderita, sebagai cara untuk meminimalisasi dampak negatif dari penyakit tersebut, khususnya dari aspek psikologis dan communibiology. Pada hakekatnya, proses komunikasi tidak hanya muncul sebagai proses sosial, tapi juga hadir sebagai proses biologis dalam diri manusia (Floyd, Mikkelson, dan Hesse, 2008). Kondisi demikian, menunjukkan bahwa komunikasi yang dilakukan keluarga pendamping penderita gagal ginjal kronis, tidak hanya muncul dari proses biologis, tapi juga berpotensi besar mempengaruhi kondisi psikologis dan biologis penderita gagal ginjal kronis. Potensi komunikasi mempengaruhi kondisi psikologis dan biologis penderita gagal ginjal kronis kemungkinan besar berkaitan dengan kemampuan komunikasi menanamkan sugesti atau beragam pesan positif kepada penderita. Karena itu, ada korelasi erat antara proses-proses biologis dalam diri individu dengan proses komunikasi, begitu pula sebaliknya. Kaitan antaran proses-proses biologis dengan proses komunikasi secara umum menjadi fokus utama perspektif kajian communibiology.

Perspektif communibiology, dalam artikel ini, digunakan untuk mengkaji fakta yang muncul di keluarga informan, tentang upaya mereka membangun dukungan bagi anggota keluarga yang mengidap gagal ginjal kronis. Pada dasarnya, penyakit gagal ginjal kronis berdampak besar pada kondisi fisiologis penderitaya, sehingga mempengaruhi cara mereka berkomunikasi secara umum, termasuk potensi munculnya agresivitas verbal kepada penderita, atau dari penderita. Meskipun pada mulanya keluarga informan dalam penelitian ini sempat mengalami ketegangan dan konflik akibat penyakit gagal ginjal kronis, namun keluarga mereka secara cepat dan efektif mengatasi konflik tersebut. Keadaan demikian menunjukkan bahwa keluarga informan bisa hidup berdampingan dan berdamai dengan penyakit gagal ginjal kronis. Situasi tersebut menunjukkan bahwa keluarga mereka bisa membangun rutinitas baru, kebiasaan baru, serta perilaku komunikasi yang baru antara penderita dengan keluarganya ataupun sebaliknya. Berdasarkan situasi dan kondisi demikian, peneliti merasa tertantang untuk mengamati proses-proses biologis yang melatarbelakangi perilaku komunikasi keluara tersebut, khususnya ketika mereka mendukung penderita gagal ginjal kronis, untuk selalu bersemangat melakukan perawatan. Sayangnya, belum banyak penelitian yang mengungkapkan proses-proses 
biologis dalam komunikasi, khususnya yang berkaitan dengan upaya membangun dukungan positif pada penderita penyakit kronis-dalam konteks ini ialah gagal ginjal. Karena itu, perspektif communibiology, dalam artikel ini, digunakan sebagai cara untuk menjelaskan secara komprehensif dan holistik tentang proses-proses biologis dan sosial dalam keluarga informan, pada saat memberikan dukungan moral positif kepada penderita gagal ginjal kronis.

Artikel jurnal ini berusaha menggambarkan secara konprehensif proses-proses biologis dalam diri informan ketika melakukan proses komunikasi untuk memberikan dukungan kepada penderita gagal ginjal kronis. Pengamatan tersebut dilakukan oleh penulis sebagai bagian dari kajian communibiology. Hal demikian mengharuskan peneliti untuk mengamati seluruh aspek biologis yang terjadi dan berkaitan dengan proses komunikasi antara keluarga dengan penderita gagal ginjal kronis, begitu pun sebaliknya. Selain itu, fakta umum bahwa penyakit gagal ginjal kronis mempengaruhi kondisi biologis - termasuk kondisi fisiologis, yang terdiri dari komponen neurologis dan endokrinologis (hormonal) — kemungkinan besar ikut mempengaruhi proses komunikasi yang dilakukan oleh masing-masing individu tersebut. Karena itu, pengamatan pada aspek biologis pada proses komunikasi keluarga, bisa mengungkap proses-proses biologis yang mendorong munculnya proses komunikasi positif ketika membangun dukungan pada penderita gagal ginjal kronis.

Artikel jurnal ini berusaha secara maksimal untuk mendapatkan jawaban komprehensif pada sejumlah pertanyaan penelitian, yaitu, 1) Bagaiamana proses komunikasi dan bentuk dukungan keluarga kepada penderita gagal ginjal kronis? 2) Bagaimana proses-proses biologis yang terjadi pada semua pihak yang terlibat dalam proses komunikasi berdasarkan kajian dan perspektif communibiology? 3) Bagaimana perspektif communibiology memberikan saran dan solusi efektif dalam rangka membangun dukungan positif kepada penderita gagal ginjal kronis? Semua pertanyaan dalam artikel jurnal ini bertujuan mendapatkan penjelasan komprehensif tentang peran aspek communibiology dalam proses komunikasi untuk membangun dukungan kepada penderita gagal ginjal kronis.

Pandangan-pandangan awal tentang peran dan kaitan antara kondisi biologis dengan perilaku sosial individu, termasuk proses komunikasi, muncul dari pemikiran sejumlah ahli fisiologi seperti Walter Cannon dan Philip Bard, serta ilmuwan-ilmuwan dari kajian communibiology, seperti Michael J. Beatty dan James C. McCroskey. Cannon dan Bard mengajukan pemikiran bahwa pengalaman emosional memunculkan perilaku-perilaku emosional pula (Bear, Connor, dan Paradiso, 2013). Pemikiran Cannon dan Bard secara sederhana menunjukkan perubahan kondisi emosional dalam diri individu mampu mengubah-ubah banyak perilaku sosial manusia menjadi tindakan sosial yang bersifat emosional. Kondisi demikian menunjukkan bahwa secara normatif perilaku komunikasi manusia dikendalikan oleh kondisi biologis dalam diri manusia. Sementara itu, Michael J. Beatty, James C. McCroskey, dan Michelle Pence (2009) mengajukan pandangan bahwa semua aktivitas sosial manusia merupakan hasil proses mental yang berkaitan dengan aktivitas otak manusia. Hal demikian, menunjukkan secara jelas bahwa aktivitas fisiologis dan neurofisiologis manusia mengendalikan perilaku manusia secara umum. Perubahan perilaku sosial manusia hadir sebagai hasil dari perubahan kondisi neurofisiologis dan kondisi hormonal dalam otak manusia. Kondisi demikian menjadi menarik, karena perubahan kecil pada kondisi fisiologis dalam otak manusia bisa memberikan dampak besar pada perubahan perilaku sosial manusia, sebagaimana dijelaskan oleh Kory Floyd, Alan C. Mikkelson, dan Colin Hesse (2008). Karena itu, pemikiran sejumlah ilmuwan di atas 
tampak saling melengkapi satu sama lain, yaitu bahwa perubahan pada kondisi fisiologis dan neurofisiologis pada otak manusia secara langsung berpengaruh pada perilaku sosial manusia.

Penelitian-penelitian yang ada selama ini mayoritas menjelaskan tentang kaitan antara perubahan psikologis dan emosional dengan kesehatan. Penelitian-penelitian seperti itu pada akhirnya bermuara pada indikasi munculnya penyakit-penyakit psikosomatis. Penelitian yang dilakukan oleh Tamara Afifi dan kawan-kawan (2015) menunjukkan bahwa tekanan sosial ekonomi berpotensi memunculkan konflik, hal demikian memunculkan potensi munculnya penyakit-penyakit psikosomatis, meskipun Afifi tidak secara langsung menyebutkan hal tersebut. Lebih jauh, Charles H. Hillman, Kirk I Erickson, dan Bradley D. Hatfield (2017) juga menyatakan bahwa perubahan kondisi kesehatan individu berkaitan erat dengan kesehatan otak dan gangguan pada aspek kognitif. Pernyataan Hillman dan koleganya menunjukkan bahwa kondisi kesehatan individu berperan pada kondisi fisiologis otak, yang pada akhirnya bisa berkaitan dengan perubahan kesehatan tubuh dan perubahan perilaku. Kondisi demikian kemungkinan besar juga berlaku pada penderita gagal ginjal kronis. Perubahan fisiologis pada penderita gagal ginjal berpengaruh pada kondisi biologis penderita, yang secara langsung mempengaruhi kondisi psikologis hingga perilakunya sosialnya, termasuk perilaku komunikasi mereka. Keadaan demikian mendoroang munculnya perubahan besar pada perilaku komunikasi keluarga dekatnya, yang juga berperan sebagai pendamping penderita gagal ginjal kronis. Karena itu, artikel jurnal ini melihat perilaku komunikasi yang dilakukan keluarga pendamping gagal ginjal untuk memberikan dukungan kepada penderita gagal ginjal, berdasarkan perspektif communibiology. Hal itu relatif jarang diamati oleh penelitian-penelitian sebelumnya.

\section{Metode Penelitian}

Peneliti menggunakan pendekatan studi kasus sebagai pendekatan metodologis dalam penelitian ini. Pendekatan studi kasus dipilih oleh peneliti, karena pendekatan tersebut memberikan kesempatan kepada penelti untuk memilih dan mengamati kasus tertentu, untuk kemudian diamati secara lebih detail menggunakan pendekatan metodologis lainnya. Robert K. Yin (2003) menyatakan bahwa studi kasus bukanlah pendetakan metodologis yang bisa digunakan untuk menguji teori atau mendeskripsikan sesuatu, namun sebagai cara untuk memilah ranah fenomena yang hendak diamati. Sederhananya, studi kasus membantu peneliti memilah suatu fenomena secara spesifik untuk kemudian dianalisis secara detail kemudian menyingkirkan hal-hal lain yang tidak berkaitan sama sekali. Sementara itu, pembahasan lebih detail akan menggunakan pendekatan kajian studi literatur. Penggunaan studi literatur menjadi pendekatan yang paling memungkinkan digunakan oleh peneliti dalam kajian communibiology, selama proses pengamatan secara empiris dengan peralatan diagnosis bantu belum memungkinkan digunakan. Pendekatan studi literatur, dalam kajian communibiology, sejalan dengan pandangan Mark Hickson III dan Don W. Stack (2010) bahwa penggunaan pensilkertas - termasuk aspek studi literatur-merupakan cara sederhana yang bisa digunakan dalam pengamatan kajian communibiology. Dengan kata lain, peneliti menggunakan studi kasus untuk menyeleksi fenomena yang secara umum diamati dalam penelitian-yaitu komunikasi keluaraga dalam upaya mendukung perawatan penderita gagal ginjal kronis, sementara pendekatan studi literatur digunakan untuk menggambarkan, membahas, dan menganalisis fenomena tersebut berdasarkan kajian communibiology.

Teknik pengambilan sampel secara purposif digunakan peneliti dalam penelitian ini, karena teknik tersebut memungkinkan peneliti untuk memilih informan berdasarkan kepemilikan 
informasinya. Hal tersebut memungkinkan peneliti untuk tidak dibatasi kuota jumlah tertentu ketika memilih infroman (Palys, 2008). Penggunaan teknik wawancara memberikan kesempatan lebih dalam bagi peneliti untuk menggali data secara lebih dalam berdasarkan pengakuan informan secara langsung, serta tidak membatasi jawaban-jawaban yang diberikan informan (Cook, 2008). Selain wawancara mendalam, peneliti menggunakan data dari literatur-literatur yang relevan dengan kajian communibiology, sebagai cara peneliti untuk menjelaskan dan menggambarkan fenomena-fenomena communibiology yang secara umum terkait dengan permasalahan yang dihadapi.

Penelitian ini menggunakan teknik analisis yang disesuaikan dengan kondisi dan permasalahan yang dihadapi. Penggunaan teknik analisis diharapkan bisa membantu peneliti memahami, menggambarkan dan menjelaskan fenomena yang dihadapi dalam penelitian ini. Secara umum, peneliti menggunakan dua tahapan teknik analisis sebagai cara memahami dan menjelaskan fenomena secara holistik. Tahapan pertama, peneliti menganalisis sejumlah data yang diperoleh dari proses wawancara mendalam. Proses analisis tersebut digunakan peneliti sebagai cara untuk memahami proses-proses yang terkait dengan kondisi informan, khususnya pada aspek komunikasi dan atau proses interaksi informan dengan penderita gagal ginjal kronis. Tahapan kedua teknik analisis mewajibkan peneliti menganalisis sejumlah data hasil analisis tahap pertama, kemudian dipahami dan dikaitkan dengan kajian tentang communibiology. Hal itu dilakukan peneliti untuk memahami dan menjelasan alasan-alasan di belakang proses komunikasi antara informan dengan penderita gagal ginjal kronis, berdasarkan kajian communibiology. Selain itu, peneliti juga bisa menggunakan hasil dari analisis tahap kedua, sebagai sarana untuk merumuskan saran efektif terkait proses komunikasi yang bisa digunakan sebagai sarana membangun dukungan positif pada penderita gagal ginjal kronis. Kedua tahap teknik analisis di atas digunakan oleh peneliti untuk membangun gambaran, penjelasan, dan analisis terkait dengan aspek communibiology dalam proses membangun dukungan positif pada penderita gagal ginjal kronis.

\section{Hasil dan Pembahasan}

\section{Komunikasi dan Dukungan Keluarga Kepada Penderita Gagal Ginjal Kronis}

Dukungan keluarga kepada penderita gagal ginjal kronis merupakan sesuatu yang dibutuhkan oleh penderita penyakit tersebut. Secara umum penderita gagal ginjal kronis mengalami perubahan fungsi-fungsi fisiologis tubuh yang kemungkinan besar berpengaruh pada perubahan emosional dan perilaku komunikasi secara umum. Hal itu memunculkan tekanan emosional bagi penderita gagal ginjal sendiri, serta situasi di sekitar penderita, terutama keluarga penderita gagal ginjal kronis. Meskipun demikian, keluarga berperan besar memberikan beragam dukungan positif kepada penderita gagal ginjal kronis, khususnya pada peningkatan semangat positif untuk terus melakukan perawatan dan pengobatan. Keluarga informan mengungkapkan sejumlah fakta penting tentang hal tersebut. Pada awalnya keluarga informan menjelaskan tekanan psikologis dan emosional yang menimpa keluarga mereka karena diagnosis bahwa anggota keluarga mereka mengidap gagal ginjal kronis. Namun demikian, keluarga informan berhasil menerima dan mengatasi kenyataan tersebut dengan, sehingga keluarga bisa memberikan dukungan positif kepada penderita gagal ginjal kronis.

Penyataan YS, saat diwawancarai, menjelaskan bahwa pada awalnya keluarga tersebut menerima benturan emosional dan psikologis, ketika menerima informasi bahwa ada anggota 
keluarga yang menderita gagal ginjal kronis. Pernyataan informan di bawah ini menunjukkan hal tersebut.

Karena kita memang orang awam, maksudnya memang tidak dari bidang kesehatanlah ya. Ya sempat drop juga, ya semuanya kalau semisal kalau kita dengar kata cuci darah itu kan sudah yang ngeri gitu ya, karena kita ndak tahu cuci darah itu seperti apa, dari keluarga juga belum pernah ada. Jadi belum bisa membayangkan sama sekali, seperti apa itu sebenarnya cuci darah - efeknya gimana dan lain sebagainya. Saya sempat drop, dia juga sempat drop, yang namanya orang kan pasti ada menolaknya kan ya, maksudnya untuk mbayangin saja sudah ngeri-ngeri gitu. (kutipan wawancara dengan YS).

Kutipan wawancara di atas menunjukkan bahwa keluarga YS mengalami tekanan psikologis dan perubahan emosional yang relatif tinggi. Keadaan demikian menjadikan keluarga YS pada awalnya terguncang secara emosional, karena perubahan mendadak pada rutinitas keluarga mereka. Di samping itu, kurangnya pengetahuan keluarga informan tentang gagal ginjal kronis meningkatkan tekanan emosional dan psikologis yang mereka rasakan selain tekanan psikologis dan emosional yang sebelumnya mereka rasakan. Keadaan demikian mendorong keluarga informan untuk beradaptasi dengan kehidupan dan rutinitas baru, yang pada awalnya relatif sulit dilakukan. Pernyataan informan di bawah ini menunjukkan kondisi tersebut.

Setahun pertama itu luar biasa perjuangan sih mbak. Beda orang beda ya. Mual, muntah, keluar masuk rumah sakit itu yang kita rasakan di awal. Jadi pasiennya pun sempat yang emosi, dalam artian adaptasi itu kan perlu. Dari A menjadi B, yang tadinya yang awalnya kegiatannya A sekarang harus seperti ini seperti itu ya itu yang gak gampang. (kutipan wawancara dengan YS)

Proses adaptasi dengan kondisi baru, yang dilakukan keluarga YS, merupakan usaha serius untuk mengurangi munculnya tekanan emosional dan psikologis. Dengan demikian, keluarga YS bisa mengembangkan cara yang relatif tepat untuk membangun dukungan kepada penderita gagal ginjal kronis — dalam hal ini sang suami.

Upaya maksimal keluarga YS mengatasi konflik untuk mencapai rutinitas baru dengan suaminya, yang menderita gagal ginjal kronis, menunjukkan bahwa keluarga tersebut berusaha meminimalisasi konflik yang muncul akibat gagal ginjal kronis. Kondisi demikian meningkatkan potensi keluarga YS untuk membangun dukungan positif kepada penderita sang suami. Selain itu, kemungkinan besar keluarga YS juga menyadari bahwa penolakan berkepanjangan pada kenyataan, bahwa sang suami menderita gagal ginjal kronis, justru tidak akan menyelesaikan masalah. Pernyataan informan di bawah ini menunjukkan hal tersebut.

Ya akhirnya sama seperti yang sama seperti mbak bilang, bisa sampai menjadi pasrah itu tadi. Yaaa...setahun pertama berat! (Ditegaskan dengan intonasi suara). Baik dari kondisi pasien maupun kita, kan juga otomatis pasti ada efeknya. ... Merasa bahwa di balik semua ini pasti ada hikmahnya. Kalau dikembalikan pada diri masing-masing pasti ada pemikiran seperti itu. Ada hikmahnya, kalau dari dia (pasien) sendiri yang awalnya agama apa...menjalankan ibadahnya kurang sekali, dengan seperti ini menjadi lebih banyak beribadah. (kutipan wawancara dengan YS)

Kutipan wawancara di atas menunjukkan munculnya usaha adaptasi keluarga penderita gagal ginjal kronis, untuk menghadapi keadaan dan rutinitas baru. Meskipun proses penerimaan tersebut ditempuh keluarga YS dengan perjuangan berat, akan tetapi hal itu merupakan penerimaan paling logis, sebab penolakan terus-menerus justru akan melemahkan struktur dalam 
keluarga YS. Hal demikian dijelaskan oleh Tamara Afifi dan rekan-rekan (2015) tekanan sosial, ekonomi, hingga tekanan psikologis yang makin besar, berpotensi memunculkan konflik dalam keluarga, namun proses komunikasi yang intens antaranggota keluarga berpotensi meningkatkan ketahanan keluarga tersebut terhadap tekanan yang diterima. Pemaparan Afifi kemungkinan besar menjadi alasan akademis tentang usaha keluarga YS untuk beradaptasi dengan kondisi yang ada. Kondisi demikian menjelaskan bahwa semakin cepat keluarga YS beradaptasi dengan kondisi baru tersebut—menghadapi penyakit gagal ginjal kronis—semakin cepat pula keluarga YS bisa menemukan solusi dari suatu masalah.

Kemampuan keluarga YS beradaptasi dengan kondisi baru memberikan mereka kemampuan untuk membangun dukungan positif kepada penderita gagal ginjal kronis, yang notabene ialah suami YS sendiri. Proses komunikasi antaranggota keluarga meningkatkan pemahaman pada anggota keluarga serta membangun kesadaran mereka untuk mengatasi masalah secara baik. Pada saat wawancara dengan peneliti, YS menyatakan bahwa ia dan keluarganya selalu memberikan semangat positif kepada sang suami (PP), yang penderita gagal ginjal kronis. Penyataan di bawah ini mengungkapkan hal tersebut

Jadi lebih-lebih, apa yang bisa dilakukan dengan pendengaran saja yang bisa dilakukan, ya udah dengan (yang tersisa) pendengarannya jadi ke agama lebih lebih, kenapa kok seperti ini, anak2 pun kok alhamdulillahnya kita kasih pengertian bahwa kondisinya tidak seperti dulu lagi. Perlu adaptasi juga, dulu kalau setiap Sabtu minggu pasti main selalu keluar, sekarang Sabtu saya harus ke sini (rumah sakit untuk cuci darah). (kutipan wawancara dengan YS)

Kutipan wawancara di atas menunjukkan bahwa keluarga YS sudah membangun penerimaan terhadap kondisi dan rutinitas baru, dalam hal ini terkait dengan kondisi gagal ginjal kronis yang menimpa suaminya. Kesadaran dan adaptasi maksimal keluarga YS menjadikan semua anggota keluarganya bisa membangun semangat positif kepada sang suami yang menderita gagal ginjal kronis. Hal demikian ditunjukkan dalam pernyataan di bawah ini

Kalau saya pribadi itu ya...lebih banyak "kita fell free aja lah" artinya cuman yaa...kita pasrah aja gitu, artinya kita mau ndak mau ya harus menjalani. ... Tapi kalau dengan ikhlas biasanya kita cenderung bisa lebih enjoy lah, bisa lebih menikmati. Jadi gitu mbak, beda lah beda kalau sama emosi. ... Anak-anak itu ya alhamdulillah, dan semoga memang terus lanjut ya mereka mau ngerti. Dia (pak puput) sendiri bilang "anak-anak itu ternyata baik-baik ya". Anak2 itu adaptasinya gampang gitu, yang tadinya cuek tapi sekarang bisa gini gini. Ya apa karena namanya anak kecil ya, mereka ngomel2 dikit karena ndak bisa keluar ya tapi sekarang dia (anak2) mau bantuin bapaknya. Contoh kalau bapaknya mau main handphone, kalau bapaknya bilang "dek kak ini tolong..." gitu mereka sigap. Itu alhamdulillah dan bersyukur, waahh anak-anakku bisa. Aku merasa lego, anak-anak bisa nrima dengan baik. (kutipan wawancara dengan YS)

Pengakuan YS, dalam wawancara di atas, menunjukkan bahwa dukungan keluarga YS terhadap sang suami, yang menderita gagal ginjal, dilakukan dengan cara membangun proses komunikasi positif. Hal itu dilakukan oleh anggota keluarga dengan cara yang sederhana, yaitu menghadapi masalah secara ikhlas serta peningkatan pada kegiatan ibadah. Selain itu, upaya membangun dukungan positif, ditunjukkan dengan usaha YS dan anak-anak mereka dengan membantu kebutuhan penderita gagal ginjal kronis, serta membangun komunikasi positif dengan sang suami-penderita gagal ginjal kronis. 
Pernyataan-pernyataan informan menunjukkan bahwa dukungan keluarga YS terhadap penderita gagal ginjal kronis dilakukan menggunakan dua cara utama. Pertama, dukungan terhadap penderita gagal ginjal dilakukan oleh keluarga dengan cara membangun keikhlasan dan penerimaan terhadap permasalahan yang dihadapi. Proses demikian ditunjukkan dengan munculnya pesan-pesan positif kepada penderita, termasuk usaha dari YS untuk tidak banyak mengeluh kepada orang lain, serta selalu membantu sang suami untuk melakukan perawatan setiap pekan. Kedua, dukungan positif keluarga YS kepada sang suami-penderita gagal ginjal — ditunjukkan oleh dukungan anak-anak mereka kepada sang ayah. Hal itu dijelaskan oleh YS dalam kutipan wawancara di atas bahwa anak-anak mereka memahami kondisi yang dihadapi keluarga, serta menunjukkan dukungan positif kepada sang ayah. Dukungan positif anggota keluarga kemungkinan besar mampu mengurangi dan mungkin menghilangkan munculnya tekanan psikologis yang dihadapi keluarga YS.

\section{Perspektif Communibiology dalam Proses Komunikasi untuk Mendukung Penderita Gagal Ginjal Kronis}

Proses biologis merupakan kunci penting yang mampu mendorong semua individu berkomunikasi. Hal serupa dikatakan Kory Floyd, Alan C. Mikkelson, dan Colin Hesse (2008) bahwa proses biologis dalam diri individu menjadikan individu mampu melakukan beragam hal termasuk berbicara serta membangun hubungan dengan lingkungan sekitarnya. Pernyataan demikian menghadirkan konsekuensi logis, yaitu bahwa proses komunikasi serta dukungan positif keluarga pada penderita gagal ginjal kronis, pasti juga hasil dari proses biologis, sehingga bisa diamati dan dijelaskan menggunakan perspektif biologis, sebagai bagian dari kajian communibiology. Secara biologis, proses komunikasi di semua ranah merupakan interaksi rumit dalam otak manusia sebagai reaksi terhadap informasi dari dunia sosial. Proses demikian melibatkan aspek patologis — kajian tentang penyebab munculnya suatu kondisi-berbicara yang melibatkan kemampuan individu mengolah, menggunakan kata (Hickson dan Stack, 2010). Secara fundamental kemampuan berkomunikasi dan berbicara merupakan proses rumit, yang berikaitan erat dengan sejumlah rumit dalam diri individu seperti aspek genetik (Onnis, Truzzi, dan Ma, 2018), terutama berkaitan dengan peran gen seperti FOXP2 (Hauser, et al, 2014). Tidak hanya itu, proses-proses fisiologis otak manusia juga ikut menentukan kemampuan individu berkomunikasi melalui pemahaman bahasa serta kemampuan berbicara. Kemampuan berbicara, berbahasa, dan berkomunikasi mayoritas dikendalikan dari pusat bicara Broca, dan pusat bahasa Wernicke (Bear, Connor, dan Paradiso, 2013). Karena itu, secara prinsip, semua bentuk komunikasi dalam upaya membengun dukungan kepada penderita gagal ginjal kronis, pasti bermula dari proses-proses biologis dan fisiologi dalam otak masing-masing individu, yang terlibat.

Proses biologis_termasuk aspek fisiologis_proses komunikasi pada keluarga YS, terkait gagal ginjal kronis dimulai ketika YS dan suaminya PP mendapatkan informasi dan diagnosis medis, bahwa sang suami menderita gagal ginjal kronis. Informasi tersebut menjadi stressor bagi YS dan sang suami, PP. Bagi YS, kondisi demikian diinterpretasikan sebagai tekanan besar yang kelak mengubah semua rutinitas mereka secara keseluruhan. Stressor tersebut mempengaruhi kondisi fisiologis dalam otak YS, khususnya pada wilayah otak yang mengendalikan emosi di limbic system, terutama bagian hypothalamus. Pengaruh terhadap bagian tersebut berdampak besar pada kondisi emosional dan perilaku YS terhadap lingkungan sekitar dan keluarganya. Karena itu, kecemasan dan ketegangan YS, ketika menerima informasi 
bahwa sang suami didiagnosis menderita gagal ginjal, menunjukkan bahwa informasi tersebut mempengaruhi kondisi fisiologis hypothalamus, dalam otak YS. Pernyataan YS pada saat wawancara juga menunjukkan bahwa ia sempat mengalami gangguan psikologis yang ditunjukkan dengan penolakan, yang berpotensi besar memicu munculkan konflik interpersonal dalam keluarga tersebut. Secara fisiologis ketegangan berlebihan bisa jadi dipicu oleh perubahan fisiologis terkait dengan kesimbangan pada aspek endokrinologis (hormonal), yang berkaitan dengan peningkatan kadar cortisol dalam darah (Cooke, et al, 2020) serta penurunan kadar serotonin (Nevid, Rathus, dan Greene, 2005) dan allopregananolone (Gunduz-Bruce, et al, 2019) dalam otak individu. Menariknya perbahan fisiologis pada hypothalamus kemungkinan besar akan mempengaruhi kondisi hormonal dalam tubuh individu, dalam konteks ini terjadi pada kondisi otak dan tubuh YS. Hal serupa, kemungkinan besar juga terjadi pada diri sang suami, PP, yang sekaligus menjadi penderita gagal ginjal. Keadaan demikian diperparah dengan sejumlah komplikasi fisiologis dalam diri PP dan perubahan kondisi sosial, yang ditunjukkan dengan fakta bahwa PP harus pensiun dini dari pekerjaannya. Situasi tersebut jelas merupakan benturan besar bagi keluarga YS secara keseluruhan, karena penyakit gagal ginjal kronis juga memberikan pengaruh besar bagi aspek finansial keluarga YS. Tekanan sosial dan ekonomi tersebut berdampak besar pada kondisi peningkatan ketegangan, kecemasan dan stress yang dirasakan oleh PP, sebagaimana dituturkan oleh YS, sang istri, dalam proses wawancara.

Menariknya, secara fisiologis, perubahan kondisi emosional dan psikologis individu bukanlah sesuatu yang bersifat statis. Meskipun hypothalamus, amygdala, dan hippocampus, yang tergabung dalam limbic system bertanggungjawab pada pengendalian proses-proses emosional dan naluri, sekaligus berkaitan erat dengan fungsi-fungsi fisiologis stress dan ketegangan (Tennison, 2010), namun wilayah tersebut tidak bekerja secara independen. Wilayah limbic system secara umum berinteraksi dengan wilayah frontal lobe, khususnya wilayah prefrontal cortex, yang berperan pada aspek logika dan kepribadian (Bear, Connor, dan Paradiso, 2013), untuk proses-proses pengendalian pada aspek emosional dan naluri. Interaksi tersebut memunculkan konsekuensi penting bahwa proses-proses naluriah secara umum bisa dikendalikan menggunakan kemampuan berpikir logis, seperti pada kondisi ketika individu harus mengendalikan amarahnya, ketika diarasa amarah tersebut justru merugikan individu. Hal demikian terjadi pada keluarga YS, ketika ia dan keluarganya lebih memilih untuk menghindari proses-proses emosional dan konflik yang dianggap merugikan. YS dan keluarganya kemudian mengganti hal-hal negatif tersebut dengan proses-proses adaptasi dan komunikasi yang lebih positif. Kesadaran tersebut ditunjukkan oleh YS dan PP yang menerima kondisi tersebut dengan ikhlas dan penerimaan yang tinggi. Situasi demikian ditunjukkan dengan pengakuan YS yang ditunjukkan dengan penggunaan pesan-pesan positif kepada sang suami, serta mengurangi penggunaan emosi negatif. Hal demikian menunjukkan bahwa YS dan suaminya, PP, memiliki pengendalian emosi yang baik serta kepribadian yang relatif baik.

Pengendalian emosi dan kepribadian, yang dimiliki oleh YS dan suaminya, PP, ditunjukkan dengan minimnya agresivitas komunikasi yang terjadi diantara mereka dengan anggota keluarga lainnya. Meskipun pada dasarnya YS mengungkapkan bahwa sang suami pernah berselisih dengan keluarga besarnya, namun hal itu terjadi jauh sebelum PP menderita gagal ginjal kronis. Sementara itu, ketika diketahui bahwa PP menderita gagal ginjal kronis, keluarga besarnya memberikan dukungan kepada PP secara tidak langsung, atau setidaknya tidak menghina keluarga YS dan PP secara verbal, akibat penyakit tersebut. Pernyataan YS dalam proses wawancara juga menunjukkan bahwa keluarganya hampir tidak pernah melakukan 
agresivitas komunikasi, namun lebih mengutamakan penggunaan bentuk komunikasi yang lebih positif. Secara biologis, penggunaan bentuk-bentuk komunikasi secara positif berkaitan dengan interaksi antara pusat bicara Broca dengan wilayah kepribadian di prefrontal cortex, sehingga mendorong individu untuk menyikapi ketegangan dengan komunikasi yang lebih positif. Meskipun pada dasarnya ada dorongan besar dari wilayah naluriah—dari wilayah limbic system untuk bertindak agresif, namun hal itu bisa segera dinetralisasi oleh wilayah logika dan kepribadian di prefrontal cortex (Fajar, 2020). Kondisi seperti itu menjadikan keluarga YS selalu berusaha untuk membangun komunikasi positif walaupun dihadapkan pada ketegangan dan tingkat stress yang tinggi akibat penyakit gagal ginjal kronis yang menimpa PP, sang suami.

\section{Kajian Communibiology untuk Mengembangkan Komunikasi Efektif pada Penderita Gagal Ginjal Kronis}

Pengendalikan emosi dan kepribadian YS dan PP mempengaruhi proses-proses fisiologis dalam otak keduanya. Hal demikian mempengaruhi kestabilan hormonal di dalam otak yang berdampak pada pengendalian emosional keduanya. Kesadaran YS dan PP untuk secara ikhlas menerima keadaan merupakan cara efektif untuk mengurangi stress dengan cara mengurangi kadar cortisol, serta meningkatkan kadar serotonin dan allopregnanolone dalam otak. Peningkatan serotonin dan allopregnanolone diketahui bisa mengurangi potensi munculnya agersivitas verbal dan agresivitas fisik, yang pada akhirnya menekan potensi konflik. Keadaan demikian mendorong YS dan PP kemungkinan besar tidak lagi memandang bahwa gagal ginjal kronis menjadi penyebab konflik utama dalam keluarganya. Kesadaran demikian menjadikan keluarga YS bisa lebih fokus pada proses perawatan penderita gagal ginjal, yang menimpa PP, sang suami.

Secara fisiologis, proses pengendalian emosi sejatinya melibatkan upaya serius dari individu untuk mengatur tingkat hormonal dalam dirinya. Hal itu dilakukan dengan cara yang beragam, namun sejatinya membutuhkan kesadaran dan kemampuan diri untuk selalu berpikir positif serta menggunakan pandangan logis untuk menahan semua amarah yang muncul. Mekanisme tentang kaitan antara pikiran positif dengan pengendalikan emosi, terkait dengan aspek hormonal memang masih belum banyak diketahui, namun secara sederhana bisa dijelaskan melalui beberapa tahapan. Pertama, pusat logika, kepribadian, dan fungsi-fungsi luhur di prefrontal cortex menerima sinyal dari pusat emosi di wilayah limbic system, terutama di hypothalamus. Di saat bersamaan, wilayah hypothalamus juga mengirimkan stimulus berupa hormon dan impuls saraf kepada organ-organ yang terkait dengan perubahan emosional, ketegangan dan kecemasan. Pada kondisi demikian, hormon-hormon steroid, seperti cortisol (Tonacci, et, al, 2019) secara langsung berpengaruh pada perubahan kondisi fisiologis tubuh, psikologis, dan perilaku individu. Menariknya, rangsangan sejumlah hormon tersebut pada wilayah prefrontal cortex mampu menjadikan sebagian individu cenderung bertindak agresif, yang pada akhirnya menjadi penyebab konflik, namun hal itu bisa saja tidak pada individu yang mampu menahan emosi dan amarahnya. Kedua, wilayah prefrontal cortex kemudian melakukan sejumlah proses kalkulasi dan pertimbangan rumit, terkait konsekuensi yang muncul dari sejumlah tindakan tertentu, jika tindakan tersebut dilakukan oleh individu. Pada tahapan ini, otak manusia dihadapkan pada dua pilihan besar, yang sama-sama kuat, yaitu tentang pilihan melakukan tindakan agresif atau tindakan non-agresif (pasifis). Kedua pilihan tersebut memiliki konsekuensi yang sama-sama besar dan pengaruh luas pada interaksi sosial individu. Ketika seseorang memilih tindakan non-agresif maka bisa dipastikan bahwa wilayah prefrontal cortex 
menyatakan bahwa tindakan non agresif dianggap lebih menguntungkan. Hal itu secara tidak langsung akan mempengaruhi keseimbangan hormon yang mempengaruhi otak manusia, seperti misalnya meningkatkan serotonin dan allopregananolone, serta menurunkan pengaruh cortisol dalam otak manusia. Keadaan demikian kemungkinan berdampak positif pada penurunan tingkat kecemasan, ketegangan, serta kecenderungan munculnya agresivitas, yang akhirnya menurunkan potensi munculnya konflik.

Pernyataan YS, dalam proses wawancara, menjelaskan bahwa ia dan suaminya, PP, selalu berpikir positif, serta membangun keikhlasan, hingga mencurahkan mayoritas kegiatannya pada hal-hal yang bersifat spiritual dan agamis. Perilaku demikian kemungkinan besar juga berdampak positif pada wilayah prefrontal cortex, dan wilayah-wilayah lainnya di otak, seperti pada wilayah naluri di limbic system. Dorongan positif terhadap wilayah-wilayah otak individu menjadikan otak memberikan impuls positif pada sejumlah organ untuk menekan sekresi sejumlah hormon yang berpotensi meningkatkan stress. Turunnya kadar hormon-hormon stress memberikan pengaruh positif pada sejumlah organ dalam individu, seperti penormalan denyut jantung, penstabilan tekanan darah, hingga berkurangnya tingkat ketegangan dan kecemasan. Hal demikian berkaitan dengan peningkatan potensi perilaku positif terutama pada perilaku komunikasi individu. Temuan di lapangan menunjukkan bahwa keluarga YS membangun komunikasi interpersonal secara baik dengan anggota keluarga lainnya, seperti dengan anakanaknya, serta komunikasinya dengan PP, sang suami. Komunikasi tersebut dilakukan YS dengan cara mengembangkan pesan-pesan positif kepada anak-anak, dengan cara membangun pemahaman tentang kondisi yang dihadapi oleh sang ayah, sekaligus suaminya. Di saat bersamaan YS juga selalu mendukung PP dengan cara selalu memberikan semangat melalui pesan-pesan yang bersifat menenangkan dan meredam kondisi emosional suaminya yang ada kalanya tidak stabil. Sementara itu PP, sang suami, juga melakukan hal-hal serupa, sehingga kemungkinan besar bisa mengurangi potensi munculnya konflik dalam keluarga tersebut. Karena itu, dukungan positif dari lingkungan sekitar, kepada keluarga penderita gagal ginjal dan penderita gagal ginjal sendiri, merupakan hal penting yang mungkin sering diabaikan. Padahal secara fisiologis, dan psikologis hal itu kemungkinan besar bisa memberikan pengaruh signifikan terdapap perilaku komunikasi.

Pada akhirnya, kajian communibiology memberikan saran yang bisa digunakan untuk mengurangi ketegangan dengan cara menstabilkan kondisi neurologis dan hormonal individu. Dukungan psikologis dari lingkungan tersedekat, seperti keluarga besar dan teman-teman dekat merupakan cara efektif untuk menanamkan semangat positif kepada keluarga penderita gagal ginjal kronis, dan penderita gagal ginjal kronis itu sendiri. Dukungan positif juga bisa , didapatkan dari peningkatan kegiatan yang bersifat spiritual dan agamis. Dukungan-dukungan positif diharapkan bisa membantu keluarga penderita dan penderita gagal ginjal kronis untuk mendapatkan ketenangan secara psikologis dan emosional. Ketenangan psikologis dan emosional bisa muncul karena keseimbangan kondisi hormonal dalam tubuh individu. Penigkatan kadar hormon seperti serotonin dan allopregnanolone, dan penurunan kadar hormon seperti cortisol menjadikan individu lebih bisa bersikap tenang dan terkendali. Kestabilan kondisi hormonal individu menjadi permulaan untuk membangun komunikasi-komunikasi positif yang dilakukan oleh keluarga penderita gagal ginjal terhadap penderita gagal ginjal, begitu pula sebaliknya. Keadaan demikian menjadikan keluarga penderita gagal ginjal bisa beradaptasi sekaligus membangun proses-proses dukungan terhadap penderita gagal ginjal kronis. 


\section{Kesimpulan}

Paparan dan penjelasan mendalam pada artikel jurnal ini menunjukkan bahwa aspek dukungan kepada penderita gagal ginjal bertumpu pada dua hal besar, berkaitan erat dengan aspek communibiology. Pertama, proses-proses biologis dalam diri semua individu yang terlibat, mulai dari masing-masing personal dalam anggota keluarga, dan juga penderita gagal ginjal itu sendiri. Proses-proses biologis dalam diri manusia, berkaitan dengan upaya membangun komunikasi positif dalam rangka membangun dukungan, ditentukan oleh sejumlah aspek penting, yaitu interaksi fisiologis antara prefrontal cortex dengan limbic system. Secara sederhana interaksi dua wilayah otak tersebut mewakili interaksi antara logika, dan kepribadian individu dengan naluri-naluri dasar individu. Pesan-pesan positif serta komunikasi non-agresif, penerimaan, dan keikhlasan, yang dijelaskan oleh informan, menunjukkan bahwa wilayah kepribadian secara aktif bisa meredam emosi negatif dan kecederungan agresivitas dalam diri individu. Kedua, interaksi komponen biologis dalam otak individu bermuara pada munculnya proses komunikasi yang baik. Proses komunikasi, yang dilakukan informan penelitian, menunjukkan bahwa keduanya berusaha maksimal menekan naluri dan kencenderungan agresivitas, dengan cara selalu membangun proses komunikasi yang baik. Hal itu menjadikan informan mampu membangun proses adaptasi terhadap rutinitas baru akibat penyakit gagal ginjal kronis.

Kemampuan keluarga membangun proses adaptasi kemungkinan besar berhubungan dengan upaya informan melakukan penerimaan terhadap keadaan yang melingkupinya. Situasi demikian muncul dalam keluarga informan, sebagai hasil dari kesadaran informan untuk selalu berpikir positif, dukungan dari lingkungan sosial terdekatnya - karib kerabat, serta menyibukkan diri pada hal-hal yang bersifat spiritual-mendalami agama. Semua hal itu kemungkinan besar menumbukan semangat positif bagi keluarga penderita gagal ginjal kronis, termasuk juga penderita gagal ginjal kronis itu sendiri, dengan cara meningkatkan kadar hormon yang berpengaruh positif pada aspek emosional, seperti serotonin dan allopregnanolone, dan mengurangi kadar hormon yang berdampak negatif seperti cortisol. Pada akhirnya, semua upaya membangun komunikasi positif bisa digunakan untuk mengurangi munculnya ketegangan dan konflik dalam keluarga penderita gagal ginjal kronis, sehingga meningkatkan kesempatan dalam keluarga tersebut untuk meningkatkan kualitas perawatan penderita gagal ginjal kronis.

\section{Ucapan Terima Kasih}

Peneliti mengucapkan terima kasih sebesar-besarnya kepada keluarga YS dan PP yang menjadi informan dalam penelitian ini, karena telah memberikan informasi berharga terkait dengan proses komunikasi yang muncul pada keluarga penderita gagal ginjal kronis. Peneliti juga mengucapkan terima kasih kepada asisten peneliti, Annisa Amalia Gusnov, yang telah mencurahkan waktunya untuk membantu peneliti mengumpulkan data, serta melakukan wawancara mendalam kepada informan penelitian. Semoga Allah membalas kebaikan semua pihak yang turut membantu terlaksananya penelitian ini. Semoga penelitian ini bisa memberikan manfaat baik bagi kalangan akademis dan masyarakat luas.

\section{Daftar Pustaka}

Afifi, T., Davis, S., Merrill, A. F., Coveleski, S., Denes, A., \& Afifi, W. (2015). In the Wake of the Great Recession: Economic Uncertainty, Communication, and Biological Stress 
Responses in Families. Human Communication Research, 41(2), 268-302. https://doi.org/10.1111/hcre.12048

Bear, M. F, Connors, B.W, \& Paradiso, M. A (2016). Neuroscience Exploring The Brain (Fourth edi). Philadelphia: Wolter Kluwers.

Beatty, J. B, McCroskey, J. C, \& Pence, M. (2009). Communibiological Paradigm. dalam Michael J. Beatty, James C. McCroskey, dan Kory Floyd (Eds) Biological Dimension of Communication, Perspective, Methods, and Research. 3-16. Cresskill: Hampton Press.

Cobley, P. (2008). Communication: Definition and Concept. dalam Wolfgang Donsbach (editor) The International Encyclopedia of Communication. 660-666. Malden: Blackwell Publishing.

Cook, K. E. (2008). In-Depth Interview. dalam Lisa M. Given (editor) The SAGE Encyclopedia of Qualitative Research Methods, Volumes 1-2. 422-423. Thousand Oaks: SAGE Publication.

Cooke, E. M., Connolly, E. J., Boisvert, D. L., Armstrong, T. A., Lewis, R. H., Kavish, N., Woeckener, M., Wells, J., \& Harper, J. (2020). Examining How Testosterone and Cortisol Influence the Relationship Between Strain, Negatif Emotions, and Antisocial Behavior: A Gendered Analysis. Crime \& Delinquency, 66(10), 1470-1501. https://doi.org/10.1177/0011128720903047

Fajar, D. P. (2020). Melacak Penyebab Agresivitas Verbal di Media Sosial Berdasarkan Perspektif Kajian Communibiology. dalam Jurnal Ilmiah Dinamika Sosial. Vol 4, No 2: 191-210.

Floyd, K, Mikkelson, A. C, \& Hesse, C. (2008). The Biology of Human Communication, second edition. Mason: Cengage Learning.

Gunduz-Bruce, H., Silber, C., Kaul, I., Rothschild, A. J., Riesenberg, R., Sankoh, A. J., Li, H., Lasser, R., Zorumski, C. F., Rubinow, D. R., Paul, S. M., Jonas, J., Doherty, J. J., \& Kanes, S. J. (2019). Trial of SAGE-217 in Patients with Major Depressive Disorder. New England Journal of Medicine, 381(10), 903-911. https://doi.org/10.1056/NEJMoa1815981

Hauser, M. D., Yang, C., Berwick, R. C., Tattersall, I., Ryan, M. J., Watumull, J., Chomsky, N., \& Lewontin, R. C. (2014). The mystery of language evolution. Frontiers in Psychology, 5. https://doi.org/10.3389/fpsyg.2014.00401

Hickson, M., \& Stacks, D. W. (2010). Biological Views of Communication. Review of Communication, 10(4), 263-275. https://doi.org/10.1080/15358593.2010.503278

Hillman, C. H., Erickson, K. I., \& Hatfield, B. D. (2017). Run for Your Life! Childhood Physical Activity Effects on Brain and Cognition. Kinesiology Review, 6(1), 12-21. https://doi.org/10.1123/kr.2016-0034

Nevid, J. S, Rathus, S. A, \& Greene, B. (2005). Psikologi Abnormal. Jilid 2. Edisi kelima. Jeanette Murad dkk (terj). Jakarta: Penerbit Erlangga.

Onnis, L., Truzzi, A., \& Ma, X. (2018). Language development and disorders: Possible genes and environment interactions. Research in Developmental Disabilities, 82, 132-146. https://doi.org/10.1016/j.ridd.2018.06.015

Palys, T. (2008). Purposive Sampling. dalam Lisa M. Given (editor) The SAGE Encyclopedia of Qualitative Research Methods, Volumes 1-2. 697-698. Thousand Oaks: SAGE Publication.

Tennison, L. R., Rodgers, L. S., Beker, D., Vorobjeva, K. I., Creed, E. T., \& Simonenko, A. (2010). Cortisol and symptoms of psychopathology in Russian and American college 
students. International Journal of Psychology, 45(3), 165-173. https://doi.org/10.1080/00207590903452309

Tonacci, A., Sansone, F., Pala, A. P., \& Conte, R. (2019). Exhaled breath analysis in evaluation of psychological stress: A short literatur review. International Journal of Psychology, 54(5), 589-597. https://doi.org/10.1002/ijop.12494

Yin, R. K. (2003). Case Study Research, Design and Methods, third edition. Thousand Oaks: SAGE Publication. 